\title{
PARASITIC NEMATODES INFECTING COMMERCIAL FISHES OFF THE COAST OF ALGERIA
}

\author{
Nassima Saadi ${ }^{*}$, Jean-Paul Trilles ${ }^{b}$, Rachid Amara ${ }^{c}$ and Zouhir Ramdane ${ }^{a}$
}

áLaboratoire de Zoologie Appliquée et d'Ecophysiologie Animale, Faculté des Sciences de la Nature et de la Vie, Université de Bejaia, Bejaia 06000, Algérie; 'Université de Montpellier, 34000 Montpellier, France; 'Univ. Littoral Côte d'Opale, Univ. Lille, CNRS, UMR 8187, LOG, Laboratoire d'Océanologie et de Géosciences, F 62930 Wimereux, France Corresponding author. Email: nassimasaadi95@gmail.com

Article history

Received: 12 March 2020;

accepted 27 May 2020

\section{Keywords:}

Anisakiasis; food safety; Anisakidae; Anisakis;

Hysterothylacium;

Trachurus

\begin{abstract}
A total of 1229 specimens representing 11 commercial fish species caught off the coast of Algeria were examined for parasitic nematodes (larvae) from November 2015 to April 2017. Four nematode species belonging to Anisakis (1 species) and Hysterothylacium (3 species) genera were identified. The presence of $A$. simplex parasitism in Trachurus trachurus was significantly related to the length $(p<0.05)$ of the fish and the season of its capture $(p<0.05)$, but not to its $\operatorname{sex}(p=$ $0.61 \%$ ). Large benthic species and some pelagic species show high rates of infection with parasitic nematodes and therefore pose considerable health risk (anisakiasis) thereby compromising food safety. An up-to-date reference checklist of nematode species collected from the North African fish species was compiled with specific relationships between parasitic nematodes and their hosts and/ or their collecting location indicated.
\end{abstract}

\section{INTRODUCTION}

Anisakids (Nematoda: Anisakidae) are parasitic nematodes whose life cycles involve crustaceans, cephalopods, fish and marine mammals (Angelucci et al. 2011). Anisakidae, especially those of the genera Anisakis Dujardin, 1845, Pseudoterranova Mozgovoi, 1951 and Contracaecum Railliet and Henry, 1912, are transmissible to humans. They can cause significant clinical diseases in fish consumers (Yagi et al. 1996; Valero et al. 2003; Martin-Sanchez et al. 2005; Petithory 2008; González et al. 2015 and Baptista-Fernandes et al. 2017) and serious negative impact on the economic prosperity of the fishing industry (Eissa et al. 2018).

Inadvertent ingestion of L3 larvae of parasitic nematodes of the genus Anisakis (Baptista-Fernandes et al. 2017) when consuming raw or undercooked seafood causes the zoonotic disease anisakiasis, which is becoming more prevalent among marine mammals and humans (Adams 1997; Audicana and Kennedy 2008; Colombo et al. 2016).

Worldwide, 14000 cases of anisakiasis, were reported from 1976 to 2002 (Audicana et al. 2002). In Japan, 2000 cases were reported per year, in the United States 50 and in Europe 500, more than $95 \%$ of which were reported in the Netherlands, Germany and Spain (Yuwalee 2015).

Larizza and Vovlas (1995) reported risks to public health associated with the appearance of larvae of the parasitic nematodes belonging to Anisakis spp. in the peritoneal cavity of Merluccius (L.) and Sardina pilchardus (Walbaum 1792), common fish species in the southern Adriatic and Ionian Seas. In Algeria, fisheries production in 2017 reached 108000 tons compared to 120000 tons in 2018. This increase in the volume of fisheries production is expected to affect the rate of fish consumption, which is currently estimated at $5 \mathrm{~kg} /$ capita/year (MDRP 2018), accordingly. In the Algerian fishing sector, little attention is given to the pathogenic fish parasites. The control of health risks associated with fishery products requires considerable effort. The quality of sea food products is very important considering the risks they may pose to consumers and the exigencies of international commerce. However, regulations defining the measures to be considered in order to mitigate the health risks related to the consumption of parasitized fish are scant. In 1996, the European Union excluded the importation of Mauritanian fish for food security reasons (Khlifa et al. 2013), which has led to major economic losses in Mauritania. In Algeria, the risks related to the presence of parasitic nematodes in fishery products are poorly known by professionals and consumers, which can be explained by the lack of taxonomic and epidemiological studies on these pathogenic parasites. The aims of the current study were: 1) to study the epidemiology of parasitic nematodes in commercial fish species from off the coast of Algeria, 2) to compile an up-to-date checklist of parasitic nematode species reported per fish host in North African waters, and 3) to provide scientific data on these parasites, which may help decision makers (risk managers) to set up a pathogen control system in our fisheries. 


\section{MATERIALS AND METHODS}

\section{Study area and fish sampling}

A total of 1229 specimens belonging to 11 teleost fish species (Pagellus erythrinus (Linnaeus 1758), Pagellus acarne (Risso 1827), Trachurus (Linnaeus 1758), Trachurus mediterraneus (Steindachner 1868), Boops boops (Linnaeus 1758), Mullus surmuletus Linnaeus 1758, Mullus barbatus barbatus Linnaeus 1758, Engraulis encrasicolus (Linnaeus 1758), Merluccius merluccius (Linnaeus 1758), Sardinella aurita Valenciennes 1847 and Sardina pilchardus (Walbaum 1792)) and $T$. trachurus, $P$. acarne and $P$. erythrinus were regularly sampled from a fishing port in the Gulf of Bejaia (eastern coast of Algeria) (Figure 1) between November 2015 and April 2017. The captured fish were transferred to the laboratory, where the length and total weight of each specimen were measured to the nearest $0.1 \mathrm{~cm}$ and the nearest $(0.1 \mathrm{~g})$, respectively.

\section{Parasitological study}

After dissection of the fish, internal organs (abdominal cavities, intestines, stomachs, livers and gonads) of each specimen were examined using a stereomicroscope. The collected parasites were preserved in alcohol $70 \%$, and their morpho-anatomy was identified using the keys available and original descriptions (Petter and Maillard 1987, 1988; Moravec 1994). The parasitological indexes were calculated according to Margolis et al. (1982) and Bush et al. (1997).

\section{Statistical analyses}

The comparison of the mean intensity (IM = number of parasites/number of infected fishes) according to the fish sex, size and seasons was tested for significance using the Student's $t$-test, non-parametrical KruskalWallis and parametrical ANOVA tests. Infection rates $(\mathrm{P} \%=$ number of infected fish/number of examined fish $\times 100$ ) (sex, size and seasons) were compared by Chisquare test. The statistical study was performed with R software (R Development Core Team 2005).

\section{RESULTS}

Among the 11 host fish species examined, 8 species were found to be infected with parasitic nematodes. Trachurus trachurus, T. mediterraneus, Mullus surmuletus, M. barbatus barbatus and Merluccius merluccius were infected with the highest number of Nematoda species (four nematode species), whereas Engraulis encrasicolus, Sardinella aurita and Sardina pilchardus were not infected with parasitic nematodes at all. The remaining fish species were found to be infected with three parasitic nematodes species (Table 1), which were mainly collected from the abdominal cavity, gonads, liver and the intestine (Figure 2; Table 1). According to our findings, Hysterothylacium aduncum (Rudolphi 1809) parasitized all infected fishes (8 species), Hysterothylacium fabri (Rudolphi 1819) and Anisakis simplex (Rudolphi 1809) infected seven and six host species, respectively (Table 1). One parasitic

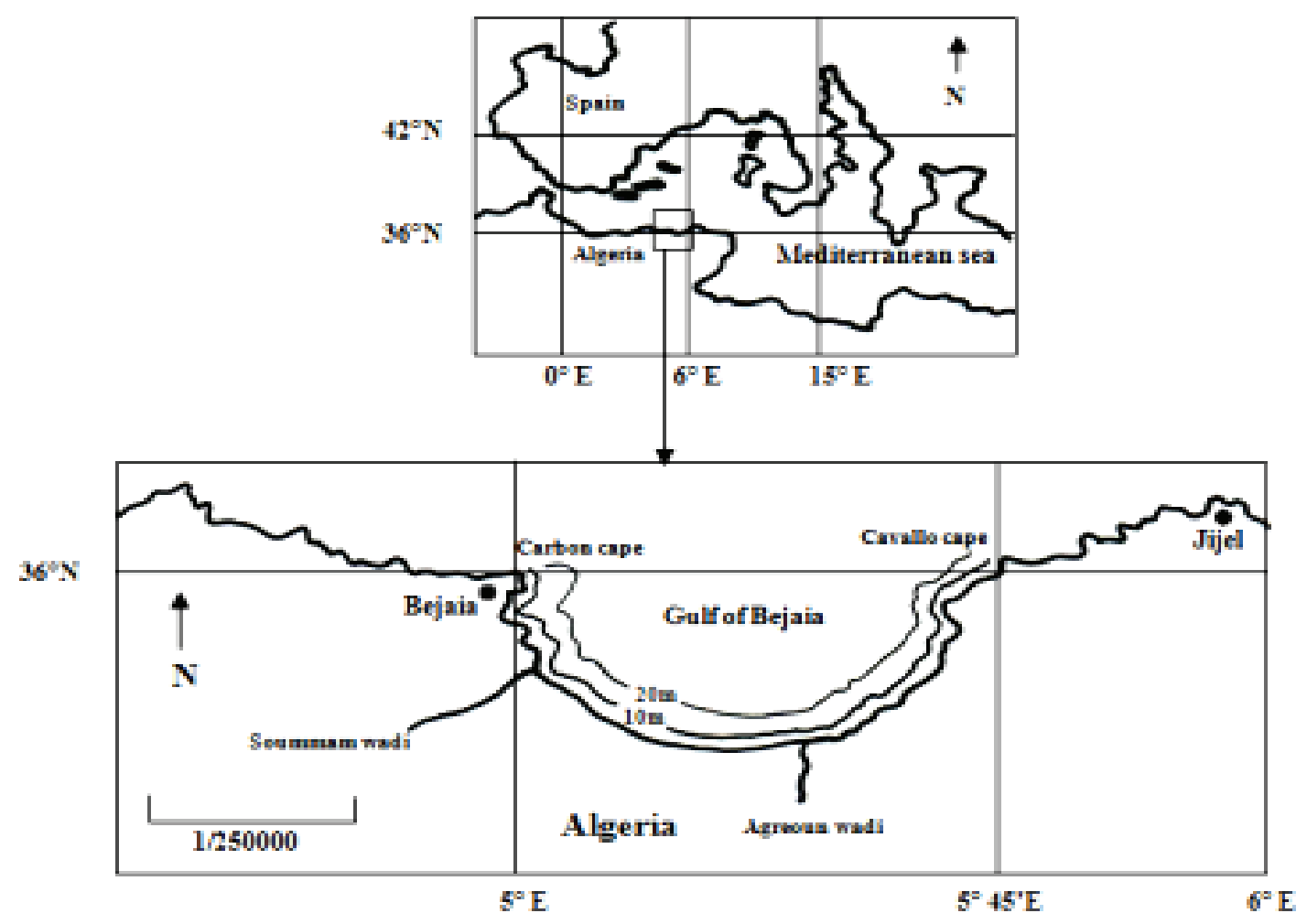

Figure 1. Location of the study area (Ider et al. 2018). 
Table 1. Parasitological indexes of the collected Nematodes.

\begin{tabular}{|c|c|c|c|c|c|c|c|c|c|}
\hline \multirow{2}{*}{ Host/parasites } & \multicolumn{2}{|c|}{ Total } & \multicolumn{2}{|c|}{ Females } & \multicolumn{2}{|c|}{ Males } & \multirow{2}{*}{$\begin{array}{l}\text { Attachment } \\
\text { sites }\end{array}$} & \multirow{2}{*}{$\begin{array}{l}\text { Statistic test } \\
\mathrm{P}(\mathrm{MI})\end{array}$} & \multirow{2}{*}{$\begin{array}{c}\text { Statistic test } \\
\mathrm{P}(\mathrm{P} \%)\end{array}$} \\
\hline & $\mathrm{P} \%$ & MI & $\mathrm{P} \%$ & MI & $\mathrm{P} \%$ & MI & & & \\
\hline \multicolumn{10}{|l|}{ Pagellus acarne $(\mathrm{n}=280)$} \\
\hline Hysterothylacium aduncum** & 30.35 & 1 & 19.62 & 1.7 & 15.94 & 1.63 & Ac, go, In & $\mathrm{P}=0.836$ & $\mathrm{P}=0.358$ \\
\hline Hysterothylacium fabri & 39.2 & 1.09 & 6.54 & 1.14 & 1.44 & 1 & In, Ac & $P=0.693$ & $\mathrm{P}=0.63$ \\
\hline Hysterothylacium sp. & 89.64 & 1.02 & 40.18 & 2.06 & 23.18 & 2.5 & Ac, In & $\mathrm{P}=0.130$ & $\mathrm{P}=0.814$ \\
\hline Total & 58.21 & 3.42 & 68.22 & 2.5 & 53.62 & 3.2 & & & \\
\hline \multicolumn{10}{|l|}{ Pagellus erythrinus $(\mathrm{n}=335)$} \\
\hline Hysterothylacium aduncum** & 30.44 & 3.68 & 31.72 & 3.48 & 3.89 & 2.21 & Ac, go, In, L & $\mathrm{P}=0.008^{*}$ & $\mathrm{P}=0.35$ \\
\hline Hysterothylacium fabri & 34.32 & 3.26 & 35.74 & 2.78 & 33.3 & 3.3 & In, Ac, go & $\mathrm{P}=0.78$ & $\mathrm{P}=0.88$ \\
\hline Hysterothylacium sp. & 33.73 & 3.59 & 34.13 & 3.51 & 2.78 & 4.7 & Ac, In & $\mathrm{P}=0.74$ & $\mathrm{P}=0.42$ \\
\hline Total & 68.95 & 7.38 & 68.67 & 7.77 & 97.22 & 5 & & & \\
\hline \multicolumn{10}{|l|}{ Trachurus trachurus $(\mathrm{n}=317)$} \\
\hline Hysterothylacium aduncum & 8.23 & 1.7 & 6.17 & 1.81 & 9.45 & 1.28 & Ac, go, In, L & $\mathrm{P}=0.352$ & $\mathrm{P}=0.663$ \\
\hline Hysterothylacium fabri & 2.43 & 1.37 & 2.80 & 1.4 & 2.70 & 1.5 & In, Ac & $P=0.270$ & $\mathrm{P}=0.628$ \\
\hline Hysterothylacium sp. & 10.06 & 2.36 & 18.53 & 2.36 & 10.81 & 2.75 & Ac, In & $\mathrm{P}=0.923$ & $\mathrm{P}=0.770$ \\
\hline Anisakis simplex & 6.30 & 1.37 & 5.61 & 1.2 & 8.10 & 1.5 & Ac, In & $P=0.611$ & $\mathrm{P}=0.208$ \\
\hline Total & 30.91 & 2.25 & 15.24 & 2.6 & 31.08 & 2.65 & & & \\
\hline \multicolumn{10}{|l|}{ Trachurus mediterraneus $(\mathrm{n}=23)$} \\
\hline Hysterothylacium aduncum** & 65.21 & 5.33 & 65 & 5.33 & 66.66 & 4 & Ac, go, In & $\mathrm{P}=0.695$ & $\mathrm{P}=0.361$ \\
\hline Hysterothylacium fabri & 4.34 & 2 & 0 & 0 & 33.3 & 2 & In, Ac & $P=0.016 *$ & $\mathrm{P}=0.62$ \\
\hline Anisakis simplex** & 13.04 & 2.33 & 15 & 2.33 & 0 & 0 & Ac, In & $\mathrm{P}=0.072$ & $\mathrm{P}=0.082$ \\
\hline Hysterothylacium sp. & 34.78 & 1.37 & 40 & 1.37 & 0 & 0 & Ac, In & $\mathrm{P}=0.001 *$ & $\mathrm{P}=0.002 *$ \\
\hline Total & 82.60 & 5.52 & 80 & 5.62 & 100 & 5 & & & \\
\hline \multicolumn{10}{|l|}{ Mullus surmuletus $(\mathrm{n}=40)$} \\
\hline Hysterothylacium aduncum** & 20 & 4.37 & 22.22 & 4.5 & 0 & 0 & Ac, go, In & $\mathrm{P}=0.002 *$ & $\mathrm{P}=0.003 *$ \\
\hline Hysterothylacium fabri & 3.75 & 3.06 & 33.33 & 3.08 & 50 & 1.5 & In, Ac & $\mathrm{P}=0.13$ & $\mathrm{P}=0.645$ \\
\hline Hysterothylacium sp. & 60 & 3.45 & 61.11 & 4.13 & 50 & 1 & Ac, In & $\mathbf{P}=\mathbf{0 . 0 0 0 7 *}$ & $\mathrm{P}=0.656$ \\
\hline Anisakis simplex** & 2.25 & 1.11 & 22.22 & 1 & 25 & 1 & Ac, In, go & $\mathrm{P}=1$ & $\mathrm{P}=0.920$ \\
\hline Total & 70 & 6.28 & 69.44 & 6.8 & 75 & 2 & & & \\
\hline \multicolumn{10}{|c|}{ Mullus barbatus barbatus $(\mathrm{n}=47)$} \\
\hline Hysterothylacium aduncum** & 14.89 & 1.42 & 13.88 & 1 & 18.18 & 2.5 & In, Ac, L & $\mathrm{P}=0.602$ & $\mathrm{P}=0.772$ \\
\hline Hysterothylacium fabri & 19.14 & 1.55 & 13.88 & 1.2 & 36.36 & 2 & In, Ac & $\mathrm{P}=0.146$ & $\mathrm{P}=0.191$ \\
\hline Hysterothylacium sp. & 21.27 & 1.3 & 13.8 & 1.2 & 45.45 & 1.4 & Ac, In & $\mathrm{P}=0.681$ & $\mathrm{P}=0.083$ \\
\hline Anisakis simplex** & 2.12 & 1 & 0 & 0 & 9.09 & 1 & In & $\mathbf{P}=0.034 *$ & $\mathrm{P}=0.340$ \\
\hline Total & 51.06 & 2.12 & 41.66 & 1.66 & 81.81 & 2.88 & & & \\
\hline \multicolumn{10}{|l|}{ Boops boops $(\mathrm{n}=55)$} \\
\hline Hysterothylacium aduncum** & 1.81 & 2 & 0 & 0 & 2.63 & 2 & Ac & $\mathrm{P}=0.5$ & $\mathrm{P}=0.323$ \\
\hline Hysterothylacium sp. & 7.27 & 1.25 & 5.88 & 2 & 7.89 & 1 & In, Ac & $\mathrm{P}=0.786$ & $\mathrm{P}=0.422$ \\
\hline Anisakis simplex** & 3.63 & 1 & 5.88 & 7 & 2.63 & 1 & Ac, In & $\mathrm{P}=1$ & $\mathrm{P}=0.618$ \\
\hline Total & 12.72 & 1 & 35.29 & 1 & 13.15 & 1.2 & & & \\
\hline \multicolumn{10}{|l|}{ Merluccius merluccius $(\mathrm{n}=12)$} \\
\hline Hysterothylacium aduncum ${ }^{* *}$ & 16.66 & 1 & 0 & 0 & 28.57 & 1 & In, Ac & $\mathrm{P}=0.091$ & $\mathrm{P}=0.172$ \\
\hline Hysterothylacium fabri & 10 & 1 & 0 & 0 & 14.28 & 1 & In, Ac & $P=0.003 *$ & $\mathrm{P}=0.355$ \\
\hline Hysterothylacium sp. & 16.66 & 1.5 & 0 & 0 & 28.57 & 1.7 & Ac, In & $\mathrm{P}=0.204$ & $\mathrm{P}=0.172$ \\
\hline Anisakis simplex** & 33.33 & 1.25 & 20 & 1 & 42.85 & 1.16 & In, go, L & $\mathrm{P}=0.183$ & $\mathrm{P}=0.440$ \\
\hline Total & 75 & 1 & 20 & 1 & 85.71 & 1.5 & & & \\
\hline Engraulis encrasicolus ${ }^{*}$ & 40 & 0 & 0 & & & & & & \\
\hline Sardinella aurita* & 40 & 0 & 0 & & & & & & \\
\hline Sardina pilchardus* & 40 & 0 & 0 & & & & & & \\
\hline
\end{tabular}

Ac: Abdominal cavity; go: Gonads; In: intestine; L: Liver; AS: Attachment site; *, Uninfected fish specimen; **: New host for A. simplex and H. aduncum; M: Mean; SD: Standard deviation; P\%: Prevalence; IM: Mean intensity; P: Probability. 

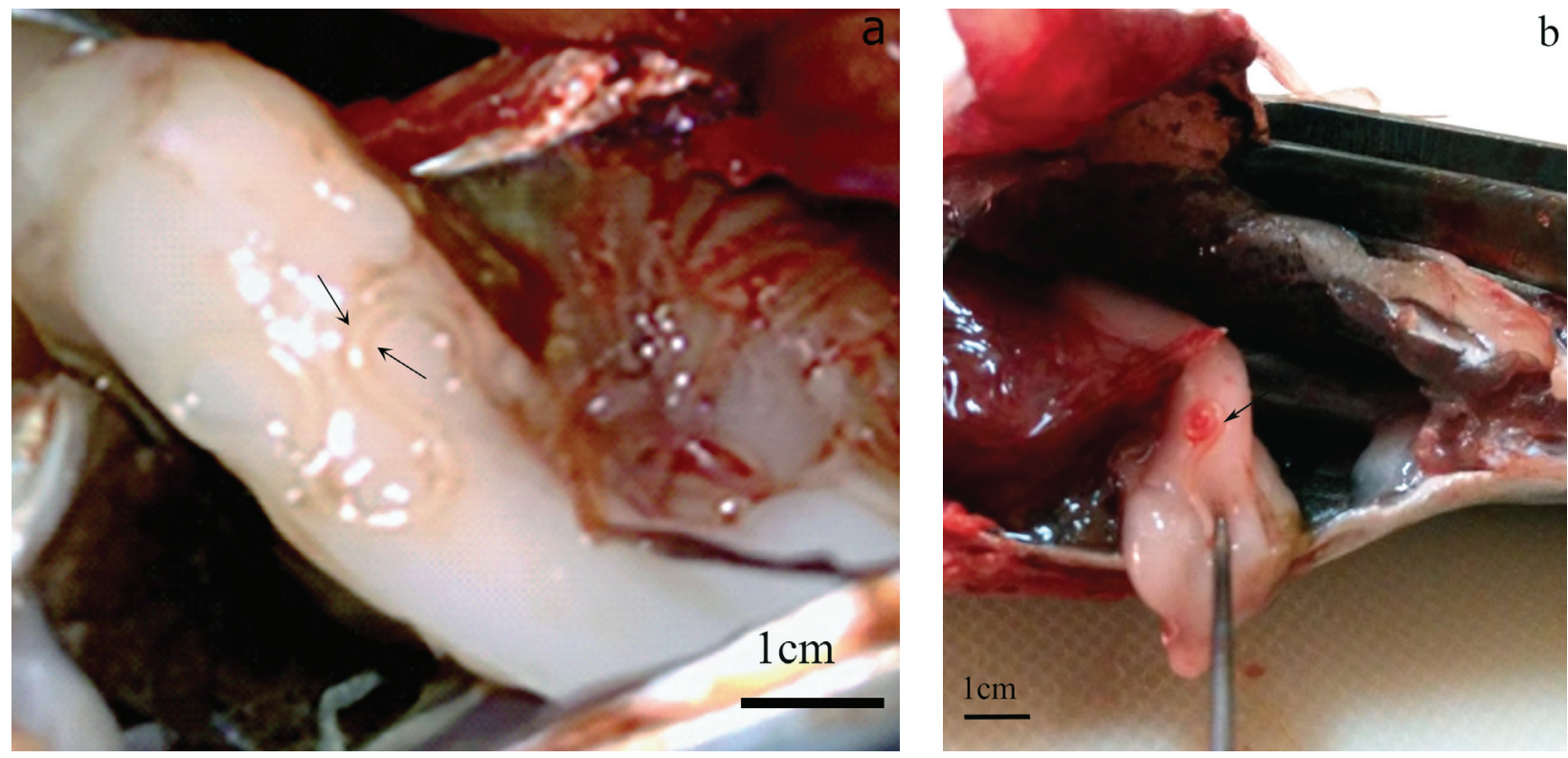

Figure 2. Anisakid larvae in the abdominal cavity of the examined teleost fish species. a, b: Anisakid larvae fixed on the male gonad of Trachurus trachurus (see dark arrow) (scale bars $=1 \mathrm{~cm})$.

nematode species $H$. fabri was newly collected from the study region and 4 new host species (T. mediterraneus, M. surmuletus, M. barbatus barbatus and M. merluccius) were recorded for the pathogenic worm A. simplex. The majority of the collected parasitic nematodes species had been already reported by several researchers from different localities of the Mediterranean Sea (Table 2). However, only 8 of these worms were reported from Algeria (Table 2). Our results show the highest infection rates in the most consumed pelagic host species, especially in T. mediterraneus $(\mathrm{P}=82.60 \%)$.

This small pelagic species could pose a risk to consumers if no prophylactic measures are taken. The highest total infection rates were also recorded in M. merluccius $(\mathrm{P}=75 \%)$, M. surmuletus $(\mathrm{P}=70 \%)$, P. erythrinus $(\mathrm{P}=68.95 \%)$ and $P$. acarne $(\mathrm{P}=58.21 \%)$ (Table 1 and Figure 3).

Hysterothylacium (Raphidascarididae) was found to exhibit higher infections rates than Anisakis (Anisakidae). Their infection rates, presented in descending order, are as follows: H. aduncum in T. mediterraneus, Hysterothylacium sp. in M. surmuletus and H. fabri in M. surmuletus. However, the lowest infection rates were recorded in Boops boops and T. trachurus. In the study area, small pelagic fish species such as E. encrasicolus, S. aurita and S. pilchardus were found to be uninfected (Table 1 and Figure 3).

There were no significant differences recorded in infection rates between males and females of $P$. acarne and B. boops (Table 1). However, significant differences in infection prevalence and/or intensity were observed between the two sexes (Table 1) in P. erythrinus, where female specimens were found to be more infected with $H$. aduncum (Table 1) than males $(p<0.05)$; in M. sur-

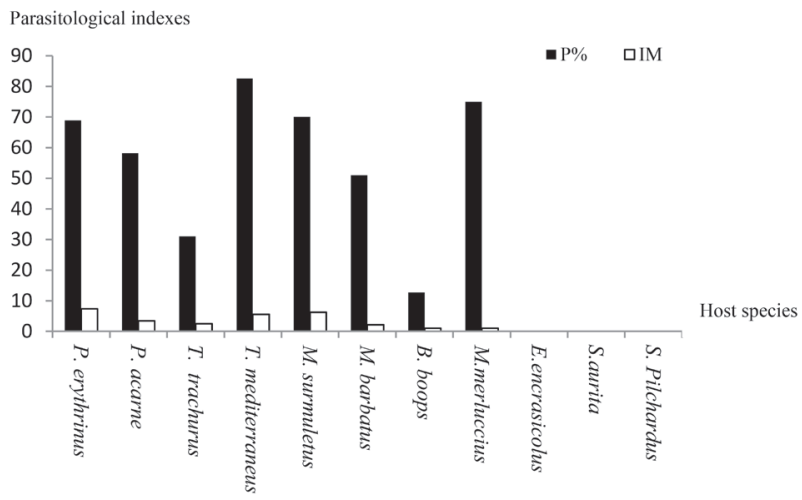

Figure 3. Variation in parasitological indexes by host species. P\%: Prevalence; IM: Mean intensity.

muletus, whose female specimens were more infected with $H$. aduncum and $H$. sp. respectively, than males $(p<0.05)$; in T. mediterraneus, whose female specimens were more infected with $H$. sp. and $H$. fabri, whose male specimens were more infected than females $(p<0.05)$; in T. trachurus, where male specimens were found to be more infected with A. simplex than females $(p<0.05)$; in $M$. barbatus barbatus, where male specimens were more infected with $A$. simplex and $H$. sp. respectively $(p<0.05)$ than females; in M. merluccius, where male specimens were more infected with $H$. fabri than females $(p<0.05)$ (Table 1).

Our results show size-dependent variation in infection rates in different fish species (T. trachurus, $P$. acarne and $P$. erythrinus) (Figure $4 \mathrm{a}, \mathrm{c}, \mathrm{e})$. The highest infection rates were recorded in larger specimens of these three fish species.

As to specimens of $T$. trachurus, the highest infection rates and mean intensity $(\mathrm{P}=70 \%, \mathrm{IM}=5.57)$ were 
Table 2. Check-list of parasite nematodes collected in the North African Coast.

\begin{tabular}{|c|c|c|c|}
\hline Parasites species & Hôtes species & Area study & References \\
\hline \multirow[t]{22}{*}{ Anisakis simplex } & Merluccius merluccius & Algeria & Petter and Maillard 1988; Present study \\
\hline & & Mauritania & Farjallah et al. 2008 \\
\hline & & Morocco & Farjallah et al. 2008 \\
\hline & Scorpaena scrofa & Algeria & Petter and Maillard 1988 \\
\hline & Trachurus trachurus & Algeria & Ichalal et al. 2015; Present study \\
\hline & & Morocco & $\begin{array}{l}\text { Farjallah et al. 2008; Kijewska et al. 2009; Azbaid et al. } \\
\text { 2016; Shawket et al. } 2017\end{array}$ \\
\hline & & Libya & Eissa et al. 2018 \\
\hline & Boops boops & Algeria & Ichalal et al. 2015; Ider et al. 2018; Present study \\
\hline & Phycis blennoides & Algeria & Hassani 2015 \\
\hline & Phycis phycis & Algeria & Hassani 2015 \\
\hline & Xiphias gladius & Tunisia & Petter and Maillard 1988 \\
\hline & Sarda sarda & Tunisia & Petter and Maillard 1988 \\
\hline & Trachurus mediterraneus & Morocco & Farjallah et al. 2008 \\
\hline & & Algeria & Present study \\
\hline & & Morocco & Farjallah et al. 2008 \\
\hline & Scomber scombrus & Morocco & Farjallah et al. 2008; Abattouy et al. 2011 \\
\hline & Scomber japonicus & Algeria & Petter and Maillard 1988 \\
\hline & & Morocco & $\begin{array}{l}\text { Shukhgalter 2004; Farjallah et al. 2008; Kijewska et al. } \\
\text { 2009; Abbatouy et al. } 2011\end{array}$ \\
\hline & Mullus surmuletus & Algeria & Present study \\
\hline & Mullus barbatus barbatus & Algeria & Present study \\
\hline & Sardina pilchardus & Algeria & Petter and Maillard 1988 \\
\hline & Micromesistius poutassou & Algeria & Petter and Maillard 1988 \\
\hline \multirow[t]{10}{*}{ Anisakis pegreffii } & Merluccius merluccius & Mauritania & Farjallah et al. 2008 \\
\hline & & Morocco & Farjallah et al. 2008 \\
\hline & Euthynnus alletteratus & Morocco & Farjallah et al. 2008 \\
\hline & Trachurus trachurus & Morocco & $\begin{array}{l}\text { Farjallah et al. 2008; Abattouy et al. 2014; Shawkat et al. } \\
2017\end{array}$ \\
\hline & & Libya & Eissa et al. 2015, 2018 \\
\hline & Trachurus mediterraneus & Morocco & Farjallah et al. 2008 \\
\hline & Scomber scombrus & Morocco & Farjallah et al. 2008 \\
\hline & Scomber japonicus & Morocco & Farjallah et al. 2008; Abattouy et al. 2011 \\
\hline & Trachyrincus scabrus & Morocco & Kijewska et al. 2009 \\
\hline & Merluccius polli & Morocco & Kijewska et al. 2009 \\
\hline \multirow[t]{5}{*}{ Anisakis typica } & Scomber scombrus & Morocco & Farjallah et al. 2008 \\
\hline & Scomber japonicus & Morocco & Farjallah et al. 2008 \\
\hline & Merluccius merluccius & Morocco & Farjallah et al. 2008 \\
\hline & Merluccius polli & Morocco & Farjallah et al. 2008 \\
\hline & Hoplostethus cadenati & Morocco & Kijewska et al. 2009 \\
\hline A. pegreffii /A. simplex s.s & Scomber japonicus & Morocco & Abattouy et al. 2011 \\
\hline \multirow[t]{6}{*}{ Anisakis physeteris } & Scorpaena scrofa & Algeria & Petter and Maillard 1988 \\
\hline & Trachipterus trachypterus & Algeria & Petter and Maillard 1988 \\
\hline & Phycis blennoides & $\begin{array}{l}\text { Algeria } \\
\text { Tunisia }\end{array}$ & $\begin{array}{l}\text { Hassani and Kerfouf } 2014 \\
\text { Farjallah et al. } 2006\end{array}$ \\
\hline & Phycis phycis & $\begin{array}{l}\text { Algeria } \\
\text { Tunisia }\end{array}$ & $\begin{array}{l}\text { Hassani } 2015 \\
\text { Farjallah et al. } 2006\end{array}$ \\
\hline & Merluccius merluccius & Morocco & Mattiucci et al. 2001 \\
\hline & Trachyrincus scabrus & Morocco & Kijewska et al. 2009 \\
\hline
\end{tabular}




\begin{tabular}{|c|c|c|c|}
\hline Parasites species & Hôtes species & Area study & References \\
\hline & Merluccius polli & Morocco & Kijewska et al. 2009 \\
\hline & Hoplostethus cadenati & Morocco & Kijewska et al. 2009 \\
\hline Anisakis brevispiculata & $\begin{array}{l}\text { Merluccius merluccius } \\
\text { Hoplostethus cadenati }\end{array}$ & $\begin{array}{l}\text { Morocco } \\
\text { Morocco }\end{array}$ & $\begin{array}{l}\text { Mattiucci et al. } 2001 \\
\text { Kijewska et al. } 2009\end{array}$ \\
\hline Anisakis ziphidarum & $\begin{array}{l}\text { Scomber scombrus } \\
\text { Merluccius merluccius } \\
\text { Hoplostethus cadenati }\end{array}$ & $\begin{array}{l}\text { Morocco } \\
\text { Morocco } \\
\text { Morocco }\end{array}$ & $\begin{array}{l}\text { Farjallah et al.2008 } \\
\text { Farjallah et al.2008 } \\
\text { Kijewska et al. } 2009\end{array}$ \\
\hline Anisakis type I & Boops boops & Algeria & Benhamou et al. 2017 \\
\hline Anisakis type II & Boops boops & Algeria & Benhamou et al. 2017 \\
\hline \multirow[t]{14}{*}{ Hysterothylacium aduncum } & Phycis blennoides & $\begin{array}{l}\text { Algeria } \\
\text { Tunisia }\end{array}$ & $\begin{array}{l}\text { Hassani and Kerfouf } 2014 \\
\text { Farjallah et al. } 2006\end{array}$ \\
\hline & Phycis phycis & $\begin{array}{l}\text { Algeria } \\
\text { Tunisia }\end{array}$ & $\begin{array}{l}\text { Hassani } 2015 \\
\text { Farjallah et al. } 2006\end{array}$ \\
\hline & Boops boops & Algeria & $\begin{array}{l}\text { Merzoug et al. 2012; Ichalal et al. 2015; Benhamou et al. } \\
\text { 2017; Ider et al. 2018; Present study }\end{array}$ \\
\hline & Trachurus trachurus & Algeria & Ichalal et al. 2015; Present study \\
\hline & Spicara maena & Algeria & Benhamou et al. 2017 \\
\hline & Merluccius merluccius & Tunisia & Amor et al. 2011 \\
\hline & & Algeria & Present study \\
\hline & Trachurus mediterraneus & Tunisia & Amor et al. 2011 \\
\hline & & Algeria & Present study \\
\hline & Pagellus erythrinus & $\begin{array}{l}\text { Tunisia } \\
\text { Algeria }\end{array}$ & $\begin{array}{l}\text { Amor et al. } 2011 \\
\text { Present study }\end{array}$ \\
\hline & Scorpaena notata & Algeria & Petter and Maillard 1988 \\
\hline & Mullus barbatus barbatus & Algeria & Present study \\
\hline & Alosa finta & Tunisia & Petter and Maillard 1988 \\
\hline & Alosa fallax & Tunisia & Petter and Maillard 1988 \\
\hline \multirow[t]{15}{*}{ Hysterothylacium fabri } & Scorpaena notata & Algeria & Petter and Maillard 1988 \\
\hline & Scorpaena elongata & Algeria & Petter and Maillard 1988 \\
\hline & Phycis blennoides & $\begin{array}{l}\text { Algeria } \\
\text { Tunisia }\end{array}$ & $\begin{array}{l}\text { Hassani and Kerfouf } 2014 \\
\text { Farjallah et al. } 2006\end{array}$ \\
\hline & Phycis phycis & $\begin{array}{l}\text { Algeria } \\
\text { Tunisia }\end{array}$ & $\begin{array}{l}\text { Hassani } 2015 \\
\text { Farjallah et al. } 2006\end{array}$ \\
\hline & Mullus surmuletus & Algeria & Hassani et al. 2015; Present study \\
\hline & Trachinus draco & Tunisia & Azizi et al. 2017 \\
\hline & Trachinus radiatus & Tunisia & Azizi et al. 2017 \\
\hline & Trachurus trachurus & Algeria & Present study \\
\hline & Pagellus acarne & Algeria & Present study \\
\hline & Pagellus erythrinus & Algeria & Present study \\
\hline & Mullus barbatus barbatus & Algeria & Present study \\
\hline & Merluccius merluccius & Algeria & Present study \\
\hline & Uranoscopus scaber & Tunisia & Petter and Maillard 1988 \\
\hline & Spicara maena flexuosa & Tunisia & Petter and Maillard 1988 \\
\hline & Boops boops & Algeria & Benhamou et al. 2017 \\
\hline Hysterothylacium sp. & $\begin{array}{l}\text { Trachinus draco } \\
\text { Trachinus radiatus }\end{array}$ & $\begin{array}{l}\text { Tunisia } \\
\text { Tunisia }\end{array}$ & $\begin{array}{l}\text { Azizi et al. } 2017 \\
\text { Azizi et al. } 2017\end{array}$ \\
\hline Anisakis sp. & $\begin{array}{l}\text { Trachinus draco } \\
\text { Trachinus radiatus }\end{array}$ & $\begin{array}{l}\text { Tunisia } \\
\text { Tunisia }\end{array}$ & $\begin{array}{l}\text { Azizi et al. } 2017 \\
\text { Azizi et al. } 2017\end{array}$ \\
\hline Hysterothylacium incurvum & Xiphias gladius & $\begin{array}{l}\text { Algeria } \\
\text { Tunisia }\end{array}$ & $\begin{array}{l}\text { Petter and Maillard } 1987 \\
\text { Petter and Maillard } 1987\end{array}$ \\
\hline $\begin{array}{l}\text { Hysterothylacium } \\
\text { bifidalatum }\end{array}$ & $\begin{array}{l}\text { Epinephelus aeneus } \\
\text { Epinephelus guaza }\end{array}$ & $\begin{array}{l}\text { Algeria } \\
\text { Algeria }\end{array}$ & $\begin{array}{l}\text { Petter and Maillard } 1987 \\
\text { Petter and Maillard } 1987\end{array}$ \\
\hline
\end{tabular}


observed in the largest specimens $(18.5-19.9 \mathrm{~cm}$ in length) (Figure 4a).

In $P$. erythrinus, the highest infection rates were also observed in the largest specimens $(18.2-18.9 \mathrm{~cm}$ in length) $(\mathrm{P}=84.21 \%, \mathrm{IM}=5.37$ (Figure $4 \mathrm{c})$. Specimens of $P$. acarne also exhibited the highest infection rate $(\mathrm{P}=89.47 \%, \mathrm{IM}=3.85)$ in the largest specimens, whose length ranged from 15.4 to $16.4 \mathrm{~cm}$ (Figure 4e).

\section{a}

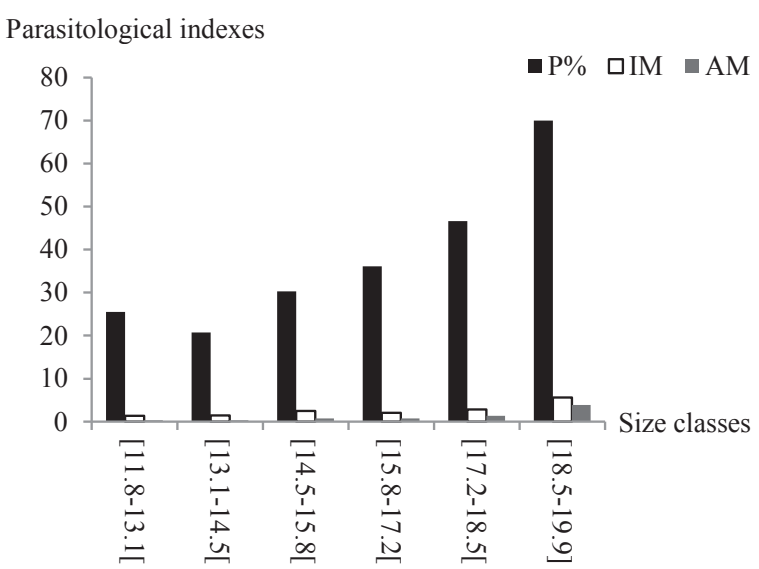

c

Parasitological indexes

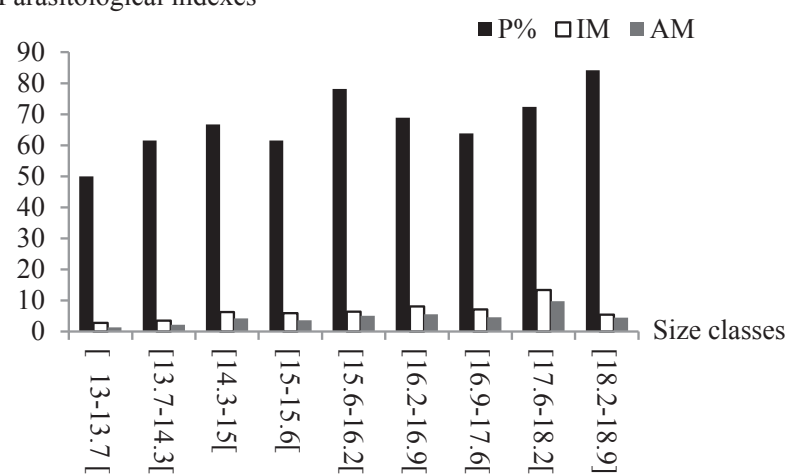

e

Parasitological indexes

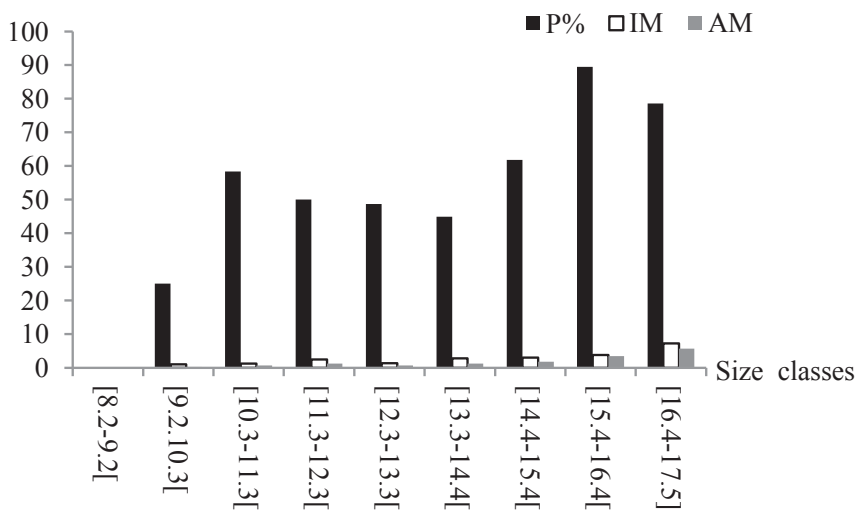

Figure 4. Variation in parasitological indexes by: a: size classes of T. trachurus; b: season of T. trachurus capture; c: size classes of P. erythrinus; d: season of P. erythrinus capture; e: size classes of P. acarne; f: season of P. acarne capture. P\%: Prevalence; IM: Mean intensity; AM: Mean abundance.
Significant differences in infection rates and mean intensities between size classes were noted in T. trachurus ( $p<0.0001$ and $p=0.0115$ respectively), in $P$. acarne $(p<0.0001$ and $p<0.0001$ respectively) and in P. erythrinus (in mean intensity, $p=0.0230$ ).

The highest infection rates in $P$. erythrinus and T. trachurus were observed in summer $(\mathrm{P}=90 \%$ and $\mathrm{P}=55.55 \%$ respectively). However in P. acarne, the

b

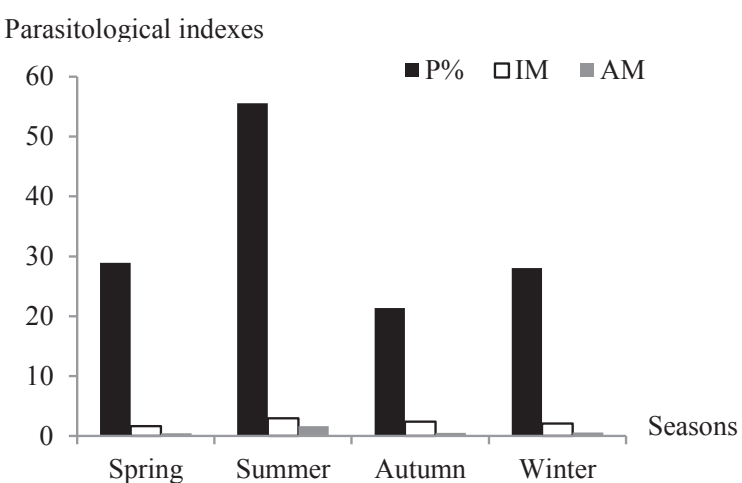

d
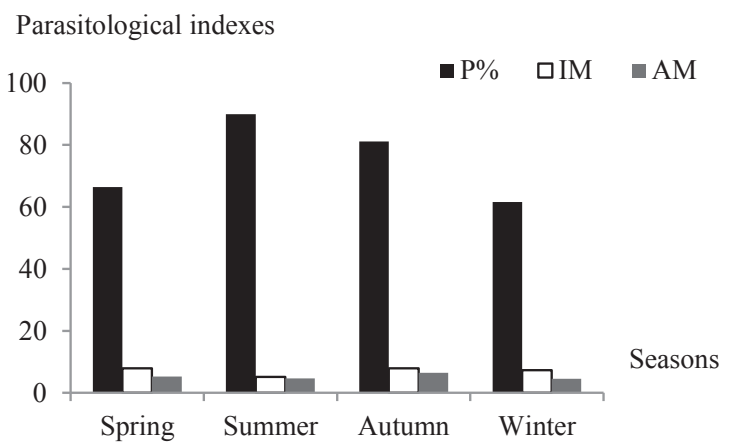

f

Parasitological indexes

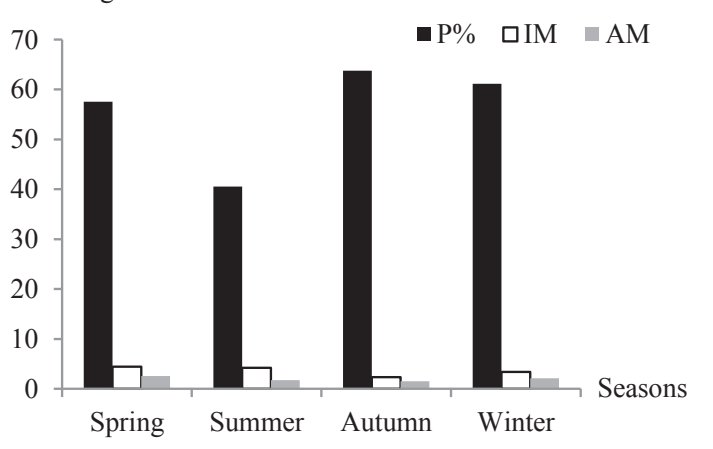


highest infestation rates $(\mathrm{P}=63.76 \%)$ were recorded in the fish caught in autumn (Figure $4 b, d$ and $\mathrm{f}$ ).

Significant differences in infection rates between seasons were noted in P. erythrinus and T. trachurus ( $p=0.0035$ and $p=0.00007$ respectively).

The specimens of $T$. trachurus, whose length ranged from 18 to $19.9 \mathrm{~cm}$, were the most infected with A. simplex $(\mathrm{P}=20 \%, \mathrm{MI}=3)$, the highest infection rate $(\mathrm{P}=12.19 \%)$ being observed in summer. The presence of A. simplex in T. trachurus was found to be not sexdependent $(p=0.61)$, but slightly significantly related to their body length $(p=0.02)$, and the season of their capture $(p=0.04)$.

\section{DISCUSSION}

Four parasitic nematodes species were identified based on their morph-anatomical details: Hysterothylacium aduncum, Hysterothylacium fabri, Hysterothylacium sp. and Anisakis simplex. In our study, the most parasitized fish species were Trachurus trachurus, T. mediterraneus, Mullus surmuletus, M. barbatus barbatus and Merluccius merluccius. One parasitic nematode, H. fabri, was collected from the study area for the first time. We found four new hosts to A. simplex in our study area (T. mediterraneus, M. surmuletus, M. barbatus barbatus and M. merluccius). Previously, this parasitic nematode was known to infect six teleost fish species in our study region.

The fish species that were found to be most infected with parasitic nematode larvae in our study included T. mediterraneus, M. merluccius, $M$. surmuletus, $P$. erythrinus, and $P$. acarne. It is possible that it is the trophic behavior of these demersal fishes (excepting T. mediterraneus) that enhances their infection with parasitic nematodes (Ichalal et al. 2015; Ider et al. 2018). Crustacean and mollusc species are generally potential prey for these fish species (Froese and Pauly 2019). Also, some fishes exhibiting pelagic behavior, such as species of the genus Trachurus, become infected with Anisakis and Hysterothylacium larvae through ingestion of their intermediate hosts such as euphausiids, copepods, and planktivorous fish (Bacha and Amara 2009; Ichalal et al. 2015; Smith 1983).

Except for P. acarne, B. boops and T. trachurus, our results showed statistical differences in infection rates between both sexes in $M$. barbatus barbatus and $M$. merluccius, where males were more infected than females, and in M. surmuletus, P. erythrinus and T. mediterraneus, where females more infected than males. Differences in infection rates of the two sexes maybe related to differences in their trophic behavior. However, Ichalal et al. (2015) reported that off the coast of Algeria, rates of fish infection with parasitic nematodes did not vary depending on the host fish sex.
Statistical differences in infection rates between size classes were observed in $P$. erythrinus and $P$. acarne infected with parasitic nematode larvae of the genus Hysterothylacium, and in T. trachurus infected with larvae of the genus Hysterothylacium and Anisakis, with larger specimens being most infected. Ichalal et al. (2015) and Abattouy et al. (2011) reported size-dependent infection rates in fish hosts from off the Mediterranean coasts of Morocco and Algeria. They postulated that intermediate prey, i. e. intermediate hosts of these parasites, constitute a significant part of large fish diet, which accounts for the increased ingestion of these parasites and, consequently, increased infection rates.

According to Abattouy et al. (2011), the highest prevalence of infection with Anisakid larvae in T. trachurus and in P. erythrinus was recorded in summer, and Eissa et al. (2018), reported that the highest prevalence of infection with A. pegreffii in T. trachurus was also observed in summer. However in P. acarne, the highest infection rates were recorded in autumn.

Variations in infection levels in the examined fish species could be related to many environmental factors (temperature, prey availability, etc.), behavior of host species (juvenile, adult, male, female), food availability (intermediate host), and feeding behavior of host fish species (pelagic, benthic).

Parasitic nematodes can affect physiological functions of fish. If the necessary prophylactic measures are not taken, consumption of infected fish could pose health risks. Further investigations into the origins of these infections and their avoidance should be carried out. It is also important that a strategy for infection mitigation and control be implemented in all Algerian fisheries. The aims should be to limit the spatio-temporal spread of infection with parasitic nematodes by regularly monitoring all commercial fish species, with particular attention being paid to those intended for export, and also, to inform consumers and decision makers about the risks these parasitic nematodes pose to human health.

\section{ACKNOWLEDGEMENTS}

We warmly thank the fishermen who helped us in getting fish samples. We thank the anonymous reviewers for their corrections and remarks.

\section{REFERENCES}

Abattouy, N., A. Valero, M. H. Benajiba, J. Lozano, and J. Martín-Sánchez. 2011. Anisakis simplex s. 1. parasitization in mackerel (Scomber japonicus) caught in the North of Morocco - Prevalence and analysis of risk fac- 
tors. International Journal of Food Microbiology 150: 136-139. doi: 10.1016/j.ijfoodmicro.2011.07.026

Abattouy, N., V. Lopez, J. L. Maldonado, M. H. Benajiba, and J. Martın-Sanchez. 2014. Epidemiology and molecular identification of Anisakis pegreffii (Nematoda: Anisakidae) in the horse mackerel Trachurus trachurus from northern Morocco. Journal of Helminthology 88: 257-263.

Adams, A. M., K. D. Murrell, and J. H. Cross. 1997. Parasites of fish and risks to public health. Revue Scientifique et Technique 16: 652-660. doi:10.20506/ rst.16.2.1059

Amor, N., S. Farjallah, P. Merella, K. Said, and B. B. Slimane. 2011. Molecular characterization of Hysterothylacium aduncum (Nematoda: Raphidascaridae) from different fish caught off the Tunisian coast based on nuclear ribosomal DNA sequences. Parasitology Research 109: 1429-1437.

Angelucci, G., M. Meloni, P. Merella, F. Sardu, S. Madeddu, R. Marrosu, F. Petza, and A. Salati. 2011. Prevalence of Anisakis spp. And Hysterothylacium spp. larvae in teleosts and cephalopods sampled from waters off Sardinia. Journal of Food Protection 74:1769-1775.

Audicana, M. T., and M. W. Kennedy. 2008. Anisakis simplex: from obscure infectious worm to inducer of immune hyper sensitivity. Clinical Microbiology Reviews 21: 360-379. doi: 10.1128/CMR.00012-07

Audicana, M. T., I. J. Ansotegui, L. F. de Corres, and M. W. Kennedy. 2002. Anisakis simplex: dangerousdead and alive? Trends in Parasitology 18: 20-25.

Azbaid, L., S. Belcaid, and E. M. Talbaoui. 2016. Anisakid Nematodes of Pagellus acarne and Trachurus trachurus, from North Atlantic Moroccan's Waters. Journal of Life Sciences 10: 279-288.

Azizi, R., C. Yemmen, and S. Bahri. 2017. Metazoan parasites of trachinid fishes (Teleostei: Trachinidae) from Tunisian coasts (Mediterranean Sea). Acta Adriatica 58: 209-224.

Bacha, M., and R. Amara. 2009. Spatial, temporal and ontogenetic variation in diet of anchovy (Engraulis encrasicolus L.) on the Algerian coast (SW Mediterranean). Estuarine Coastal and Shelf Sciences 85: 257-264.

Baptista-Fernandes, T., M. Rodrigues, I. Castro, P. Paixao, P. Pinto-Marques, L. Roque, S. Belo, P. M. Ferreira, K. Mansinho, and C. Toscano. 2017. Human gastric hyper infection by Anisakis simplex: A severe and unusual presentation and a brief review. International Journal of Infectious Diseases 64: 38-41.

Benhamou, F., D. Marzoug, Z. Boutiba, A. Kostadinova, and A. Pérez-Del-Olmo. 2017. Parasite communities in two sparid fishes from the western Mediterranean: a comparative analysis based on samples from three localities off the Algerian coast. Helminthologia 54: 26-35.

Bush, A. O., K. D. Lafferty, J. M. Lotz, and A.W. Shos- tak.1997. Parasitology meets ecology on its own terms: Margolis et al. revisited. Journal of Parasitology 83: 575-583.

Colombo, F., P. Cattaneoa, M. Castellettia, and C. Bernardia. 2016. Prevalence and Mean intensity of Anisakidae parasite in seafood caught in Mediterranean Sea focusing on fish species at risk of being raw-consumed. A meta-analysis and systematic review. Critical Reviews in Food Science and Nutrition 56: 1405-1416.

Eissa, A. E., M. Abdelsalam, A. Abumhara, A. Kammon, F. T. Gammoudi, K. Ben Naser, T. Ibrahim, and A. Asheg. 2015. First Record of Vibrio vulnificus / Anisakis pegreffi concurrent infection in black scorpionfish (Scorpaena porcus) from the South Mediterranean Basin. Research Journal of Pharmaceutical, Biological and Chemical Sciences 6: 1537-1548.

Eissa, A. E., Md., L. Showehdi, M. M. Ismail, A. S. ElNaas, A. A. Abu Mhara, and S. K. Abolghait. 2018. Identification and prevalence of Anisakis pegreffii and A. pegreffi -A. simplex (s. s.) hybrid genotype larvae in Atlantic horse Mackerel (Trachurus trachurus) from some North African Mediterranean coasts. Egyptian Journal of Aquatic Research 44: 21-27.

Farjallah, S., B. B. Slimane, H. Blel, N. Amor, and K. Said. 2006. Anisakid parasites of two forkbeards (Phycis blennoides and Phycis phycis) from the eastern Mediterranean coasts in Tunisia. Parasitology Research 100: $11-7$.

Farjallah, S., M. Busi, M. O. Mahjoub, B. B. Slimane, L. Paggi, K. Said, and S. D'Amelio. 2008. Molecular characterization of larval Anisakid Nematodes from marine fishes off the Moroccan and Mauritanian coasts. Parasitology International 57: 430-436.

Froese, R., and D. Pauly. (eds). 2019. FishBase. World Wide Web electronic publication. www.fishbase.org.

González-Amores, Y., E. Clavijo-Frutos, C. Salas-Casanova, and G. Alcain-Martínez. 2015. Direct parasitologial diagnosis of infection with Hysterothylacium aduncum in a patient with epigastralgia. Revista Espanola de Enfermedades Digestivas 107: 699-700.

Hassani, M., and A. Kerfouf. 2014. Diversity of Nematodes from the greater forkbeard Phycis blennoides (Teleostei: Gadidae) in the Western Mediterranean Sea. International Journal of Sciences: Basic and Applied Research 18: 97-103.

Hassani, M. 2015. Inventaire des Nématodes des Poissons Gadidés: Phycis blennoides (Brûnnich, 1768) et Phycis phycis (Linné, 1758) du littoral oranais (ouest Algérien). Thèse Doctorat. Universite djillaliliabes sidi bel abbes. Algérie. [Inventory of Gadidae Nematodes: Phycis blennoides (Brûnnich, 1768) and Phycis phycis (Linné, 1758) from the Oran coast (west of Algeria). Doctoral thesis. djillaliliabes sidi bel abbes University. Algeria].

Hassani, M., A. Kerfouf, and Z. Boutiba. 2015. Checklist 
of helminth parasites of Striped Red Mullet, Mullus surmuletus (Linnaeus, 1758) (Perciformes: Mullidae), caught in the Bay of Kristel, Algeria (western Mediterranean). Check List 11: 1504. doi:http://dx.doi. org/10.15560/11.1.1504

Ichalal, K., Z. Ramdane, D. Ider, M. Kacher, M. Iguerouada, J. P. Trilles, L. Courcot, and R. Amara. 2015. Nematodes parasitizing Trachurus trachurus (L.) and Boops boops (L.) from Algeria. Parasitology Research 114: 4059-4068.

Ider, D., Z. Ramdane, J. P. Trilles, and R. Amara. 2018. Metazoan parasites of Boops boops (Linnaeus, 1758) from the Algerian coast. Cahiers de Biologie Marine 59: 225-233. doi.org/10.21411/CBM.A.6F8096B3

Khlifa, S., E. Faliex, P. Sasal, and R. Galzin. 2013. Étude de l'infestation par des larves d'Anisakidés de trois espèces de poissons d'intérêt économique en Mauritanie [Study of the infestation by Anisakidae larvae of three species of fish of economic interest in Mauritania]. Cybium 37: 39-48.

Kijewska, A., A. Burzyn'ski, and R. Wenne. 2009. Anisakid parasites of fishes caught on the African shelf. Journal of Parasitology 95: 639-645.

Larizza, A., and N. Vovlas. 1995. Morphological observations on third-stage larvae of Anisakis simplex (Anisakidae: Nematoda) from Adriatic and Ionian waters. Journal of the Helminthological Society of Washington 62: 260-264.

Martin-Sanchez, J., M. E. Artacho-Reinoso, M. DiazGavilan, and A. Valero-Lopez. 2005. Structure of Anisakis simplex $\mathrm{s}$. 1. populations in a region sympatric for A. pegreffii and A. simplex s. s. Absence of reproductive isolation between both species. Molecular \& Biochemical Parasitology 141: 155-162.

Margolis, I., W. Esche, J. C. Holmes, A. M. Kuris, and G. A. Schad. 1982. The use of ecological terms in parasitology (report of an ad hoc committee of the American Society of Parasitologists. Journal of Parasitology 68: 131-13.

Marzoug, D., Z. Boutiba, A. Kostadinova, and A. Pérez-delOlmo. 2012. Effects of fishing on parasitism in a sparid fish: contrasts between two areas of the Western Mediterranean. Parasitology International 61: 414-420.

Mattiucci, S., L. Paggi, G. Nascetti, E. Abollo, S. C. Webb, S. Pascual, R. Cianchi, and L. Bullini. 2001. Genetic divergence and reproductive isolation between Anisakis brevis piculata and Anisakis physeteris (Nematoda: Anisakidae). International Journal of Parasitology 31: 9-14.

MDRP. 2018. Pêche et aquaculture en Algérie, situation et enjeux économiques [Fisheries and Aquaculture in Algeria, situation and economic issues]. http://www. fao.org/fi/staticmedia/MeetingDocuments/BlueHope/ Inception/Presentatio s/
Moravec, F. 1994. Parasitic Nematodes of Freshwater Fishes of Europe. Academia and Prague and Dordrecht: Kluwer Academic Publishers.

Petithory, J. C. 2008. Actualité sur l'anisakidose [News on anisakidosis]. Revue francophone des laboratoires 38: 87-93.

Petter, A. J., and C. Maillard. 1987. Ascarides de poissons en Méditerranée Occidentale [Ascarid fish in the Western Mediterranean]. Bulletin du Muséum National d'Histoire Naturelle 9: 773-798.

Petter, A. J., and C. Maillard. 1988. Larves d'ascarides parasites de poissons en Méditerranée Occidentale [Ascarid larvae, parasitic fish in the Western Mediterranean]. Bulletin du Muséum National d'Histoire Naturelle 10: 347-369.

R Development Core Team. 2005. R: a language and environment for statistical computing. Vienna, Austria: R Foundation for Statistical Computing.

Ramdane, Z., J. P. Trilles, K. Mahé, and R. Amara. 2013. Metazoan ectoparasites of two teleost fish, Boops boops (L.) and Mullus barbatus L. from Algerian coast: diversity, parasitological index and impact of parasitism. Cybium 37: 59-66.

Shawket, N., A. El Aasri1, Y. Elmadhi, I. M'Bareck, K. El Kharrim, and D. Belghyti. 2017. Anisakis simplex (Nematoda: Anisakidae) from horse mackerel (Trachurus trachurus) in Atlantic coast of Morocco. Asian Pacific Journal of Tropical Disease 7: 463-466.

Shukhgalter, O. A. 2004. Parasite fauna of the chub mackerel (Scombridae: Scomber japonicas Houttuyn, 1782) in the Central-Eastern Atlantic Ocean (the Atlantic coast of the North Africa and the Azores banks). Parasitologiya 38: $160-170$.

Smith, J. W. 1983. Anisakis simplex (Rudolphi, 1809, det. Krabbe, 1878) (Nematoda: Ascaridoidea): morphology and morphometry of larvae from euphausiids and fish, and a review of the life-history and ecology. Journal of Helminthology 57: 205-224.

Valero, A., S. Terrados, V. Díaz, V. Reguera, and J. Lozano. 2003. Determination of $\operatorname{IgE}$ in the serum of patients with allergic reactions to four species of fish-parasite anisakids. Journal of Investigational Allergology and Clinical Immunology 13: 94-8.

Yagi, K., K. Nagasawa, H. Ishikura, A. Nagasawa, N. Sato, K. Kikuchi, and H. Ishikura. 1996. Female worm Hysterothylacium aduncum excreted from human: a case report. Japanese Journal of Parasitology 45:12-23.

Yuwalee, S. 2015. Caractérisation des Anisakidae dans les poissons marins: développement d'une méthode d'identification par séquençage à haut-débit et étude de prévalence [Characterization of Anisakidae in marine fish: development of a high-throughput sequencing identification method and prevalence study]. Thèse de Doctorat en parasitologie. Université Lille, France. 